\title{
Michał Machura
}

Instytut Języka Polskiego Polskiej Akademii Nauk

\section{Teksty modlitw eucharystycznych w świetle najnowszych zasad pisowni słownictwa religijnego}

Niniejszy artykuł jest spojrzeniem na teksty modlitw eucharystycznych $^{1} \mathrm{z}$ punktu widzenia najnowszych zasad pisowni słownictwa religijnego, opublikowanych w listopadzie 2011 r. pod tytułem Pisownia słownictwa religijnego (R. Przybylska, W. Przyczyna, Biblos, Tarnów 2011). Zasady te, na wniosek Komisji Języka Religijnego i Komisji Ortograficzno-Onomastycznej Rady Języka Polskiego przy Prezydium Polskiej Akademii Nauk, zostały zatwierdzone przez samą Radę na posiedzeniu plenarnym 22 listopada 2010 roku i obowiązują tym samym wszystkich użytkowników polszczyzny.

Zapisy w tekstach modlitw eucharystycznych zostały podzielone, podobnie jak w artykułach traktujących o pisowni w tekstach prefacji ${ }^{2}$, na dwie grupy: te, które występują w tytułach, i te, które odnajdujemy w sa-

Według Ogólnego wprowadzenia do mszału rzymskiego (pkt 78) modlitwa eucharystyczna to „modlitwa dziękczynienia i uświęcenia, która jest ośrodkiem i szczytem całej celebracji. Kapłan wzywa lud, aby wzniósł serce do Pana, oraz jednoczy go z sobą w modlitwie i dziękczynieniu, jakie w imieniu całej wspólnoty zanosi do Ojca przez Jezusa Chrystusa w Duchu Świętym. Znaczenie tej modlitwy polega na tym, aby całe zgromadzenie wiernych zjednoczyło się z Chrystusem w głoszeniu wielkich dzieł Bożych i w składaniu ofiary. Modlitwa eucharystyczna domaga się, aby wszyscy wsłuchiwali się w nią w pełnym czci skupieniu".

Por. M. Machura, W. Przyczyna, Mszał rzymski w świetle zasad pisowni słownictwa religijnego (na przykładzie tekstów prefacji), [w:] Mundus verbi. In honorem Sophiae Cygal-Krupa, red. M. Pachowicz, K. Choińska, Tarnów 2012, s. 332-338; M. Machura, W. Przyczyna, Prefacje mszalne w świetle zasad pisowni słownictwa religijnego z 2011 roku, [w:] Cum reverentia, gratia, amicitia... Księga jubileuszowa dedykowana Profesorowi Bogdanowi Walczakowi, red. J. Migdał, A. Piotrowska-Wojaczyk, Poznań 2013, t. II, s. 339-344. 
mych tekstach. W nawiasach podano odnośniki do konkretnych zasad pisowni (rozdział i podrozdział).

Przykłady do analizy zaczerpnięto z Modlitw eucharystycznych do koncelebry (Pallottinum, Poznań 1986)³.

\section{Zapisy w tytułach}

W Modlitwach eucharystycznych do koncelebry tytuły modlitw występują w trzech miejscach: w tekstach, w żywej paginie i w spisie treści, zamieszczonym na końcu. Ponieważ w tym pierwszym miejscu zapisano je wersalikami, w dalszej części artykułu zostaną omówione te wersje, które spotykamy w żywej paginie i w spisie treści:

1) Pierwsza Modlitwa eucharystyczna, czyli Kanon rzymski;

2) Druga Modlitwa eucharystyczna;

3) Trzecia Modlitwa eucharystyczna;

4) Czwarta Modlitwa eucharystyczna;

5) Piąta Modlitwa eucharystyczna;

6) 1. Modlitwa eucharystyczna o tajemnicy pojednania;

7) 2. Modlitwa eucharystyczna o tajemnicy pojednania.

Każdy z tytułów został zapisany niepoprawnie, zgodnie bowiem z zasadami (I.7.2) w nazwach własnych konkretnych modlitw wielką literą piszemy tylko pierwszy człon. W tym kontekście poprawne są formy:

1) Pierwsza modlitwa eucharystyczna, czyli Kanon rzymski ${ }^{4}$;

2) Druga modlitwa eucharystyczna;

3) Trzecia modlitwa eucharystyczna;

4) Czwarta modlitwa eucharystyczna;

5) Piąta modlitwa eucharystyczna;

6) 1. modlitwa eucharystyczna o tajemnicy pojednania;

7) 2. modlitwa eucharystyczna o tajemnicy pojednania.

${ }^{3}$ W publikacji tej nie ujęto modlitw eucharystycznych z udziałem dzieci, ponieważ nie są one przewidziane do mszy koncelebrowanych.

$4 \quad$ Kanon rzymski to alternatywny tytuł Pierwszej modlitwy eucharystycznej. W tym przykładzie znalazł się dodatkowo błąd interpunkcyjny: w oryginale brakuje przecinka przed czyli, co jest złamaniem reguły 385 WSO (Wielki słownik ortograficzny PWN, red. E. Polański, Warszawa 2010). 
Niezależnie od powyższych zapisów zgodne z zasadami (I.7.3) będą takie warianty, jak: pierwsza modlitwa eucharystyczna, druga modlitwa eucharystyczna, trzecia modlitwa eucharystyczna, czwarta modlitwa eucharystyczna czy piąta modlitwa eucharystyczna, które jednak - w odróżnieniu od nazw własnych - są określeniami opisowymi, czyli nazwami gatunkowymi. Należy je rozumieć jako „pierwsza, druga, trzecia... z kolei modlitwa eucharystyczna".

\section{Zapisy w tekstach}

Błędy w tekstach modlitw eucharystycznych zostały zaznaczone pogrubionym drukiem. W nawiasie podano źródło cytatu: I ME - I modlitwa eucharystyczna, II ME - II modlitwa eucharystyczna, III ME - III modlitwa eucharystyczna, IV ME - IV modlitwa eucharystyczna, V ME - V modlitwa eucharystyczna, I METP - I modlitwa eucharystyczna o tajemnicy pojednania, II METP - II modlitwa eucharystyczna o tajemnicy pojednania.

1) [...] zesłał na Apostołów Ducha Świętego (I ME, II ME, III ME);

2) [...] Duch Święty zstąpił na Apostołów (I ME, III ME);

3) [...] Twoich świętych Apostołów i Męczenników, [...] z Twoimi świętymi Apostołami i Męczennikami (I ME); [...] ze świętymi Apostołami i Męczennikami (III ME)/[...] z Apostołami i Męczennikami (V ME);

4) [...] przyjąłeś dary swojego sługi, sprawiedliwego Abla, i ofiarę naszego Patriarchy Abrahama (I ME);

5) [...] pouczałeś ich przez Proroków (IV ME);

6) [...] niech Twój święty Anioł zaniesie (I ME);

7) [...] ze czcią wspominamy [...] wszystkich Twoich Świętych (I ME);

8) [...] uroczyście obchodzimy dzień poświęcony pamięci wszystkich Świętych (II ME, III ME).

W przykładach 1-8 mamy do czynienia z określeniami gatunkowymi, $\mathrm{w}$ dodatku występującymi niejednokrotnie w liczbie mnogiej (przykłady $n r$ 1, 2, 3, 5, 7 i 8), więc użycie wielkiej litery jest niezgodne z zasadami (I.1.11, I.1.14 i I.23.3). Poprawne zapisy to: apostołowie, męczennicy, (wszyscy) święci, prorocy, anioł i patriarcha.

9) [...] naszym Papieżem N. i naszym Biskupem N. (I ME, I METP); [...] naszym Papieżem N., naszym Biskupem N. (II ME, II METP); [...] naszego Papieża N., naszego Biskupa N. (III ME); [...] naszym Papieżu N., o naszym Biskupie N. (IV ME); [...] między kapłanami i naszym Biskupem N., między biskupami i naszym Papieżem N. (V ME). 
Zgodnie z zasadami (I.10.1) nazwy godności, tytułów i urzędów kościelnych zapisujemy przeważnie małymi literami, wielkie litery w przykładzie nr 9 są zatem niepożądane. Z zacytowanymi fragmentami wiąże się jednak jeszcze jeden błąd - interpunkcyjny. W I modlitwie eucharystycznej czytamy bowiem: „[...] razem z Twoim sługą, naszym Papieżem N. i naszym Biskupem N. oraz wszystkimi, którzy strzegą wiary katolickiej i apostolskiej". Błąd polega na niepostawieniu przecinka po konstrukcji apozycyjnej „Twoim sługą, naszym Papieżem N.” (człon apozycyjny „naszym Papieżem N.” powinien zostać wydzielony przecinkami). Sługą Boga jest bowiem - zgodnie z intencją modlitwy - papież (a nie papieżi biskup, gdyż wówczas należałoby napisać „Twoimi sługami” i postawić dwukropek), niezbędny jest więc przecinek zamykający wtrącenie: „[...] razem z Twoim sługą, naszym papieżem N., i naszym biskupem N. oraz wszystkimi, którzy strzegą wiary katolickiej i apostolskiej”.

10) [...] ze czcią wspominamy najpierw pełną chwały Maryję, zawsze Dziewicę, Matkę Boga (I ME);

11) [...] uroczyście obchodzimy dzień, w którym została poczęta bez grzechu pierworodnego Maryja, wybrana na Matkę Zbawiciela (I ME);

12) [...] uroczyście obchodzimy dzień, w którym została poczęta bez grzechu pierworodnego Najświętsza Maryja Panna, wybrana na Matkę Jezusa Chrystusa (II ME);

13) [...] uroczyście obchodzimy dzień, w którym została wzięta do nieba Najświętsza Dziewica Maryja, Matka Twojego Syna (II ME);

14) [...] Twój Syn Jednorodzony, Światłość ze Światłości, został przedstawiony w świątyni (I ME, III ME);

15) [...] Ty jesteś Zbawicielem świata (I ME, II ME, III ME, IV ME, V ME, I METP, II METP);

16) Przez Jezusa Chrystusa, Arcykapłana dóbr przyszłych, prosimy Ciebie, wszechmogący Boże (II ME);

17) [...] Twój Syn, jedyny Sprawiedliwy, wydał się w nasze ręce i pozwolił się przybić do krzyża (I METP);

18) Ty stworzyłeś człowieka na swoje podobieństwo i powierzyłeś mu cały świat, aby służąc Tobie samemu jako Stwórcy, rządził wszelkim stworzeniem (IV ME);

19) [...] Ty Go wezwałeś, aby zasiadł po Twojej prawicy, jako nieśmiertelny Król wieków i Pan całego wszechświata (V ME).

Wyrazy i wyrażenia użyte w przykładach 10-19, w dużej mierze dopowiedzenia, wskazują na funkcje, jakie pełnią poszczególne desygnaty: Maryja,Jezus i Bóg Ojciec, więc niewskazane jest, aby zapisywaćje wielkimi literami (I.1.3), zwłaszcza że wcześniej pojawiło się w tekście albo właściwe imię („Maryja” w przykładzie nr $10 \mathrm{i}$ 11, ,Jezus Chrystus” w przykładzie nr 16), albo peryfraza („Najświętsza Maryja Panna” w przykładzie nr 12, „Najświętsza Dziewica 
Maryja” w przykładzie nr 13, „Syn Jednorodzony” w przykładzie nr 14), albo zaimek osobowy (,Tobie” - Bogu Ojcu w przykładzie nr 18, „Go” - Jezusa Chrystusa w przykładzie nr 195), jasno wskazujący, że chodzi o osobę boską.

20) [...] z Najświętszą Bogurodzicą Dziewicą Maryją (II ME).

W przykładzie nr 20 wskazane jest oddzielenie przecinkiem peryfrazy Maryi „Najświętsza Bogurodzica” od pozostałej części zacytowanego fragmentu, która stanie się wówczas dopowiedzeniem. To z kolei pociągnie za sobą konieczność użycia małej litery (jak w przykładach 10-19): „[...] z Najświętszą Bogurodzicą, dziewicą Maryją".
21)[...] składamy Tobie tę Ofiarę uwielbienia, [...] przyjmij łaskawie tę Ofiarę, [...] uświęć tę Ofiarę (I ME); [...] składamy Ci, Ojcze, Ofiarę pojednania (II METP); [...] Ofiara na- szego pojednania z Tobą (III ME).

Termin „ofiara (mszy świętej)” zapisujemy, zgodnie z zasadami, małymi literami (I.21.5). Wielkie litery są pożądane jedynie w przypadku wyrażenia „Najświętsza Ofiara” (I.9.1). Warto zaznaczyć, że o ile w wielu miejscach występuje zapis wielką literą, o tyle na przykład w II modlitwie eucharystycznej o tajemnicy pojednania czytamy: „Przez ofiarę Jezusa Chrystusa [...]”.

22) [...] stała się dla nas Ciałem i Krwią Twojego umiłowanego Syna (I ME); [...] posileni Ciałem i Krwią Twojego Syna (III ME); [...] Jego Ciało i Krew (IV ME);

23) [...] składamy Twojemu najwyższemu majestatowi z otrzymanych od Ciebie darów Ofiarę czystą, świętą i doskonałą, chleb święty życia wiecznego i Kielich wiekuistego zbawienia (I ME);

24) [...] ofiarujemy Tobie, Boże, Chleb życia i Kielich zbawienia (II ME); Umocnij swój lud Chlebem życia i Kielichem zbawienia (V ME);

25) Ile razy ten Chleb spożywamy i pijemy z tego Kielicha (V ME, I METP, II METP).

Wyrażenie „ciało i krew Pańska” zapisujemy zasadniczo małymi literami (I.23.2), pomijając przymiotnik dzierżawczy „Pański”, więc wszelkie

5 W przykładzienr 19, jako” oznacza,,w roli” i nie wprowadzawyrażenia o charakterze przyczynowo-uzasadniającym. Przecinek jest zatem zbędny (por. reguła 382 WSO). Zdanie należy bowiem rozumieć następująco: Bóg wezwał Jezusa, aby zasiadł po jego prawicy w roli króla wieków i pana wszechświata. Wypowiedzenie z przecinkiem niosłoby zaś taką treść: Jezus jest królem wieków i panem wszechświata, więc Bóg posadził go po swojej prawicy, inaczej: Bóg posadził Jezusa po swojej prawicy, ponieważ jest on (Jezus) królem wieków i panem wszechświata, także: Bóg jest królem wieków i panem wszechświata, więc wezwał Jezusa, aby zasiadł po jego prawicy, inaczej: Bóg wezwał Jezusa, aby zasiadł po jego prawicy, ponieważ jest on (Bóg) królem wieków i panem wszechświata. 
peryfrazy ciała i krwi Chrystusa również powinny być pisane z zachowaniem tej reguły, czyli: „chleb życia” i „,kielich zbawienia”, „chleb święty życia wiecznego" i „kielich wiekuistego zbawienia”. Na uwagę zasługuje fakt, że o ile w V modlitwie eucharystycznej i obu modlitwach o tajemnicy pojednania użyto wielkich liter (por. przykład nr 25), o tyle w pozostałych, tj. I, II, III i IV modlitwie eucharystycznej - małych. To kolejny przejaw ortograficznej niekonsekwencji w mszale.

O pisowni rzeczownika „ofiara” (por. przykład nr 23) była mowa w poprzednim akapicie.

26) Obchodząc pamiątkę śmierci i zmartwychwstania Twojego Syna, który jest naszą Paschą i naszym pokojem, i oczekując błogosławionego dnia Jego przyjścia na końcu czasów, składamy (I METP).

W tym kontekście rzeczownik „pascha” nie jest synonimem święta Wielkanocy (inaczej: Paschy), więc zapis wielką literą jest niedopuszczalny.

27) Przyjmij do swojego Królestwa (III ME); [...] O dobry Ojcze, daj nam, swoim dzieciom, dziedzictwo życia wiecznego [...] w Twoim Królestwie (IV ME); Wspieraj nas we wspólnym budowaniu Twojego Królestwa (I METP).

Rzeczownik „królestwo (niebieskie)” w pierwszym i drugim fragmencie jest synonimem nieba, więc powinien być pisany małą literą (I.22.12); w trzecim odnosi się raczej do królestwa Bożego ${ }^{6}$, jednak i to pojęcie należy zapisywać małymi literami (poza przymiotnikiem dzierżawczym „Boży”; I.21.1). W zacytowanych przykładach zwraca również uwagę niewłaściwa forma zaimków dzierżawczych. Zgodnie z zasadami (III.3.9) zaimków „twój”, „twoja”, „twoje” używamy wtedy, gdy podmiot czynności nie jest równocześnie właścicielem przedmiotu. W tym przypadku natomiast przedmiot (czyli królestwo) należy do podmiotu czynności (czyli Boga Ojca), więc zasadne jest użycie zaimków „swój”, „,swoja”, ,swoje”. Ostatnie dwa fragmenty powinny zatem przybrać postać: „O dobry Ojcze, daj nam, swoim dzieciom, dziedzictwo życia wiecznego [...] w swoim królestwie”; ,Wspieraj nas we wspólnym budowaniu swojego królestwa”. Jak widać, w odniesieniu

6 Królestwo Boże to rzeczywistość zapoczątkowana przez Chrystusa wraz z Jego pierwszym przyjściem na ziemię, Kościół jest jej zalążkiem (por. KKK 567, Katechizm Kościoła katolickiego na www.katechizm.opoka.org.pl). 
do dzieci użyto w mszale właściwej formy zaimka, w odniesieniu do królestwa - nie (mowa o drugim fragmencie, gdyż w pierwszym zastosowano poprawny zaimek: „swojego”).

28) Wysławiamy Cię, Ojcze święty (IV ME, V ME); Wejrzyj, Ojcze święty (V ME);

29) Boże, Ojcze miłosierdzia, daj nam Ducha Świętego (V ME);

30) [...] Tobie, Boże, Ojcze wszechmogący, w jedności Ducha Świętego (I ME, II ME, III ME, IV ME, V ME, I METP, II METP);

31) Wysławiamy Cię, Boże wszechmogący, Panie nieba i ziemi, przez Jezusa Chrystusa (II METP).

W przywołanych we wstępie artykułach poświęconych błędom w tekstach prefacji autorzy zaproponowali pisownię peryfraz wielką literą w dwu przypadkach: gdy wyrażenie omowne zastępuje imię właściwe (np. „Oddajemy cześć Panu Wszelkiego Stworzenia" [Bogu]) i gdy występuje w wołaczu, czyli jako zwrot adresatywny (np. „Chwała Tobie, Jezu Chryste, Królu Wiecznej Chwały"). W pozostałych użyciach zalecono zapis małą literą, zwłaszcza wówczas, gdy peryfraza wskazuje jedynie funkcję, jaką pełni desygnat (np. "Jezus, odkupiciel człowieka, umarł na krzyżu za nasze grzechy”; I.1.3).

Przytoczone wyżej reguły w dużej mierze korespondują z zasadami pisowni zaimków odnoszących się do Boga: gdy zwracamy się bezpośrednio do Stwórcy, używamy wielkiej litery, gdy natomiast tylko o nim wspominamy - już niekoniecznie (I.1.4).

Kierując się tą argumentacją, należałoby napisać: Wysławiamy Cię, Ojcze Święty [Boże]; Wejrzyj, Ojcze Święty [Boże]; Boże, Ojcze Miłosierdzia; Tobie, Boże, Ojcze Wszechmogący; Wysławiamy Cię, Boże Wszechmogący, Panie Nieba i Ziemi.

„Ojciec Święty”, „Ojciec Miłosierdzia”, „Ojciec Wszechmogący” i „Pan Nieba i Ziemi” to peryfrazy Boga (Ojca) (I.22.1 i I.22.2), atrybut „wszechmogący” w zestawieniu „Bóg Wszechmogący” jest zaś dodatkowym określeniem identyfikującym, wskazującym - ze względu na położenie w postpozycji - na cechę trwałą desygnatu. Podobne określenia, które są de facto skonwencjonalizowanymi tytułami osób boskich czy Maryi, zgodnie z zasadami zapisujemy wielką literą (I.1.3).

32) [...] przez udział w tej Uczcie eucharystycznej daj nam swego Ducha (II METP).

W przykładzie nr 32 mamy do czynienia z peryfrazą Eucharystii. Według ogólnej zasady pisowni peryfraz (peryfraza desygnatu, który wymaga wiel- 
kiej litery, powinna być pisana wielkimi literami, a peryfraza desygnatu, który wymaga małej litery - małymi; I.22) wyrażenie, o którym mowa, należałoby zapisać wielkimi literami: „Uczta Eucharystyczna”. Z tego samego powodu wielkich liter używamy w peryfrazach Boga (por. przykłady 28-31), odnoszą się one bowiem do desygnatu, który wymaga wielkiej litery.

33) [...] ze świętym N. (III ME).

Atrybut „święty” łączy się trwale z imieniem, tworząc wielowyrazową nazwę własną osoby świętej. Za łączeniem przemawia fakt, że bez wspomnianej przydawki desygnat byłby niejednokrotnie nierozpoznawalny, np. „Mikołaj” - jakiś człowiek o imieniu Mikołaj (nazwa własna osoby w ogóle), ale: „Święty Mikołaj” - święty Pański, biskup Miry w Azji Mniejszej (nazwa własna osoby świętej, I.1.9). W konsekwencji należy zapisać „Święty N.”, gdzie „N.” zastępuje dowolne imię. Inaczej byłoby, gdyby między atrybutem a imieniem znalazł się dodatkowy rzeczownik. Wówczas ten rzeczownik rozbijałby szyk nazwy własnej, co wiązałoby się z koniecznością użycia małych liter, np. „święty biskup Mikołaj” (I.1.9).

34) [...] świętego Józefa, Oblubieńca Najświętszej Dziewicy (I ME).

Atrybut „święty” w przykładzie nr 35 wchodzi w skład osobowej nazwy własnej, więc powinien zostać zapisany wielką literą (skrót „św.” - małą), czyli: „Święty Józef” albo „św. Józef” (por. przykład nr 34). Peryfraza, która występuje po przecinku, jest dopowiedzeniem determinującym funkcję, jaką w Świętej Rodzinie pełni Święty Józef, nie ma zatem potrzeby, aby zapisywać ją wielkimi literami (uwaga ta nie dotyczy samej peryfrazy Maryi: „Najświętsza Dziewica”). Inaczej byłoby w kontekstach, o których wspomniano wyżej: gdyby peryfraza zastępowała właściwe imię lub wystąpiła jako zwrot adresatywny, nawet obok imienia.

Jak wynika z przeanalizowanych przykładów, najpoważniejsze błędy w tekstach modlitw eucharystycznych dotyczą zdecydowanie zbyt częstego użycia wielkiej litery i niewłaściwej pisowni peryfraz. Choć na pochwałę zasługuje fakt, że poprawnie, tj. małą literą (I.19), zapisano nazwy wydarzeń zbawczych ${ }^{7}$, to nie zwalnia on jednak osób zaangażowanych w przygotowa-

W większości przypadków, ponieważ w I, II i III modlitwie eucharystycznej jest mowa o tym, że „uroczyście obchodzimy (świętą noc) święty dzień Zmartwychwstania naszego Pana Jezusa 
nie kolejnej edycji Mszału rzymskiego dla diecezji polskich z odpowiedzialności za wyeliminowanie pozostałych niedociągnięć, które w niniejszym artykule szczegółowo przedstawiono.

Należy podkreślić, że przy ocenie poprawności zapisów występujących w tekstach modlitw eucharystycznych kierowano się zasadniczo względami znaczeniowymi, a nie uczuciowymi. Podobne kryterium przyjęli zresztą autorzy Pisowni słownictwa religijnego. Piszący może, oczywiście, indywidualnie użyć wielkiej litery w przypadkach, o których mowa w regułach 97, 98 i 99 WSO, lecz powinien korzystać z tej swobody świadomie i odpowiedzialnie. Stosowanie wielkiej litery z rzekomych przyczyn emocjonalnych nie może usprawiedliwiać niekompetencji językowej danego użytkownika. Takie bezrefleksyjne praktyki wyjątkowo szkodzą naszemu systemowi językowemu, ponieważ wielka litera traci wówczas swoją zasadniczą rolę - przestaje wyodrębniać desygnaty, którym przysługuje status nazwy własnej.

\section{The texts of eucharistic prayers from the perspective of recent religious vocabulary spelling rules}

The article discusses the texts of eucharistic prayers from the perspective of recent religious vocabulary spelling rules approved by the Polish Language Council in 2010 and published in 2011. The article presents the characteristics of the most common linguistic errors that appear in the titles and texts of prayers. Both of them concern misspellings and punctuation errors. The first group of aberrations concern too frequent use of the capital letter and the wrong spelling of periphrases. The Author admit that although the writers may use capital letter by emotional reasons, nevertheless, they should use this consciously and responsibly as to not to obliterate the differences of meaning between words.

Keywords: Polish language standard, religious vocabulary, eucharistic prayers

Słowa kluczowe: polska norma językowa, słownictwo religijne, modlitwy eucharystyczne

Chrystusa". Chodzi wszak o dzień, w którym nasz Pan zmartwychwstał, czyli o dzień zmartwychwstania, a nie o nazwę uroczystości, bo ta brzmi de facto inaczej: „uroczystość Zmartwychwstania (Pańskiego)”, względnie: „dzień Zmartwychwstania (Pańskiego)”, także: „Zmartwychwstanie (Pańskie)”. Wyrażenie „dzień zmartwychwstania naszego Pana” może się, oczywiście, odnosić i do uroczystości, lecz w takim brzmieniu ma charakter raczej opisowy (por. „dzień poświęcony pamięci wszystkich świętych”, ale: „uroczystość (dzień) Wszystkich Świętych”).

8 R. Przybylska, W. Przyczyna, Pisownia słownictwa religijnego, Tarnów 2011, s. 10-11. 